\title{
Hydrologic flow path development varies by aspect during spring snowmelt in complex subalpine terrain
}

\author{
Ryan W. Webb ${ }^{1}$, Steven R. Fassnacht ${ }^{2}$, and Michael N. Gooseff ${ }^{1}$ \\ ${ }^{1}$ Institute of Arctic and Alpine Research, University of Colorado, Boulder, CO 80309, USA \\ ${ }^{2}$ Department of Ecosystem Science and Sustainability, Colorado State University, Fort Collins, CO 80523, USA
}

Correspondence: Ryan W. Webb (ryan.w.webb@colorado.edu)

Received: 1 February 2017 - Discussion started: 9 March 2017

Revised: 17 November 2017 - Accepted: 6 December 2017 - Published: 23 January 2018

\begin{abstract}
In many mountainous regions around the world, snow and soil moisture are key components of the hydrologic cycle. Preferential flow paths of snowmelt water through snow have been known to occur for years with few studies observing the effect on soil moisture. In this study, statistical analysis of the topographical and hydrological controls on the spatiotemporal variability of snow water equivalent (SWE) and soil moisture during snowmelt was undertaken at a subalpine forested setting with north, south, and flat aspects as a seasonally persistent snowpack melts. We investigated if evidence of preferential flow paths in snow can be observed and the effect on soil moisture through measurements of snow water equivalent and near-surface soil moisture, observing how SWE and near-surface soil moisture vary on hillslopes relative to the toes of hillslopes and flat areas. We then compared snowmelt infiltration beyond the nearsurface soil between flat and sloping terrain during the entire snowmelt season using soil moisture sensor profiles. This study was conducted during varying snowmelt seasons representing above-normal, relatively normal, and below-normal snow seasons in northern Colorado. Evidence is presented of preferential meltwater flow paths at the snow-soil interface on the north-facing slope causing increases in SWE downslope and less infiltration into the soil at $20 \mathrm{~cm}$ depth; less association is observed in the near-surface soil moisture (top $7 \mathrm{~cm}$ ). We present a conceptualization of the meltwater flow paths that develop based on slope aspect and soil properties. The resulting flow paths are shown to divert at least $4 \%$ of snowmelt laterally, accumulating along the length of the slope, to increase the snow water equivalent by as much as $170 \%$ at the base of a north-facing hillslope. Results from this study show that snow acts as an extension of the vadose
\end{abstract}

zone during spring snowmelt and future hydrologic investigations will benefit from studying the snow and soil together.

\section{Introduction}

In many mountainous headwater catchments snow and soil moisture are key components of the hydrologic cycle, providing valuable information pertaining to the dynamic processes that occur during spring runoff. This has justified large data collection efforts to further understand the distribution of snow and soil moisture across landscapes during the winter and spring seasons (Elder et al., 2009). During spring, much snowmelt will infiltrate into the soil with a noticeable change in soil moisture prior to recharging groundwater storage, producing streamflow, or contributing to evapotranspiration (Bales et al., 2011; Kampf et al., 2015; Webb et al., 2015). The relative saturation in the vadose zone controls the stream connectivity and release of water and nutrients from subsurface storage into stream systems (McNamara et al., 2005; M. W. Williams et al., 2009). Soil moisture during this time is driven by snowmelt that can impact the water availability for plant production (Molotch et al., 2009; Harpold et al., 2015) as well as the ionic signature of soil moisture and stream flow (Harrington and Bales, 1998). For these reasons the connections between snowmelt and soil moisture are critical in understanding the hydrologic cycle in snow-dominated headwater systems (Jencso et al., 2009), particularly in the face of a changing climate that will alter the snowmelt season and resulting hydrological dynamics (Adam et al., 2009; Clow, 2010; Clilverd et al., 2011; Harpold et al., 2012; Rasmussen et al., 2014; Fassnacht et al., 2016). 
Processes within headwater catchments such as snow accumulation and persistence are known to vary at multiple scales of interest. From a basin-scale perspective, elevation has been shown to influence the depth and persistence of a snowpack (Richer et al., 2013; Molotch and Meromy, 2014; Sexstone and Fassnacht, 2014), while at finer resolutions the spatial variability of both accumulation and melt may be controlled by aspect (C. J. Williams et al., 2009; López-Moreno et al., 2013; Hinckley et al., 2014), and snow in forested areas is affected by interception during accumulation, shortwave radiation shading, and longwave radiation influences prior to and during melt (Storck et al., 2002; Musselman et al., 2008; Molotch et al., 2009; Adams et al., 2011; Webb, 2017). However, far less is known about the variability that snowmelt has on soil moisture and flow paths during snowmelt at the hillslope scale, in large part due to the difficulty of observing soil moisture beneath a deep snowpack at high spatial resolution. Snowmelt is important to soil moisture storage and resulting streamflow (McNamara et al., 2005; C. J. Williams et al., 2009; Bales et al., 2011; Hunsaker et al., 2012; Kormos et al., 2014). Stream connectivity to the surrounding landscape follows seasonal trends with the highest connectivity during spring snowmelt based on factors such as topography (McNamara et al., 2005; Jencso et al., 2009; Jencso and McGlynn, 2011). The aspect of a hillslope will additionally increase soil water storage and retention on north aspect slopes (Geroy et al., 2011) that can alter runoff processes and result in spatially variable soil moisture beneath a melting snowpack.

There have been recent advancements in the ability to observe soil moisture throughout the water year in capturing high-resolution data at both spatial and temporal scales (e.g., Bales et al., 2011). Similar advances have occurred for observing variables such as the liquid water content of a snowpack (Mitterer et al., 2011; Techel and Pielmeier, 2011; Koch et al., 2014; Heilig et al., 2015). This has allowed for further understanding of hydrological systems and dynamic processes that are vulnerable to climate change (Bales et al., 2006). However, observations of the relative saturation of soil beneath a snowpack has been limited to an array of discrete points with sufficient instrumentation, and few studies have investigated spring snowmelt soil moisture at a scale similar to that used to measure the snow above it. The few studies that have observed these process have shown microtopography to influence infiltration across the snow-soil interface (SSI; French and Binley, 2004) and that wetter areas tend to remain wetter, with slope and aspect being important factors at a low-elevation site (C. J. Williams et al., 2009). In highelevation alpine environments topography and wind shielding influences soil moisture distribution, though there is less association with these parameters in low snow years (Litaor et al., 2008). These studies, limited to high-alpine and low rain-snow transition zones, suggest that topographic influences on soil moisture are strong but more investigations during varying snow accumulation, melt dynamics, and environ- ments are important to connect the distribution of soil moisture across a landscape to runoff processes, particularly with variable regional and environmental snowpack responses to climate variability (Harpold et al., 2012).

The relative saturation of the vadose zone determines runoff processes during spring snowmelt (McNamara et al., 2005). Runoff processes have been shown to change during spring snowmelt compared to summer rain events (Eiriksson et al., 2013; Williams et al., 2015). During snowmelt, soil moisture is influenced mostly in the top $10 \mathrm{~cm}$ of soil (Blankinship et al., 2014) with pulses of water that reach further depths varying widely at both the hillslope and catchment scale (Webb et al., 2015). At the catchment scale a south aspect hillslope may display matrix flow during snowmelt as the north aspect displays evidence of preferential flow through the soil (Hinckley et al., 2014). Preferential flow paths have been shown to occur both in the soil beneath a snowpack (French and Binley, 2004) and above the ground surface within the snowpack (Marsh and Woo, 1985; Kattelmann and Dozier, 1999; Williams et al., 2000; Liu et al., 2004; Williams et al., 2010). Preferential flow within a snowpack can form as the result of ice lenses (Colbeck, 1979) or differences in grain size and density (Avanzi et al., 2016; Webb et al., 2018). Each of these can alter the flow of water through snow and resulting infiltration into the soil, from the centimeter scale (Williams et al., 2010) up to tens of meters (Eiriksson et al., 2013; Webb et al., 2018). Preferential flow paths within a snowpack will create spatially variable snowmelt patterns across a landscape depending on the variable metamorphism that occurs within the snowpack (Yamaguchi et al., 2010; Adams et al., 2011; Domine et al., 2013; Katsushima et al., 2013), which increases during melt (Marsh, 1987). These melt patterns have been shown to have correlation lengths of 5 to $7 \mathrm{~m}$ in relatively flat alpine terrain (Sommerfeld et al., 1994; Williams et al.,1999) and lesser correlation lengths of 2 to $4 \mathrm{~m}$ in subalpine terrain (Webb, 2017). Preferential flow paths within a snowpack will alter soil moisture and resulting runoff processes at the hillslope and catchment scales.

To our knowledge there have been no studies investigating snow and soil moisture interactions specifically to investigate hydrologic flow path development in a subalpine environment beneath a deep $(2 \mathrm{~m})$ seasonally persistent snowpack. The goal of this study is to gain further understanding through observations of flow path development in a snowmelt-dominated subalpine headwater catchment. Observations of near-surface soil volumetric water content (VWC) were compared to topographical parameters (e.g., slope, aspect) and hydrological variables (e.g., temperature, date of peak snow water equivalent). Statistical analysis of the topographical and hydrological controls on the spatiotemporal variability of snow and soil moisture during snowmelt was undertaken at a subalpine forested setting with north, south, and flat aspects as a seasonally persistent snowpack melts with the following objectives: (1) to inves- 


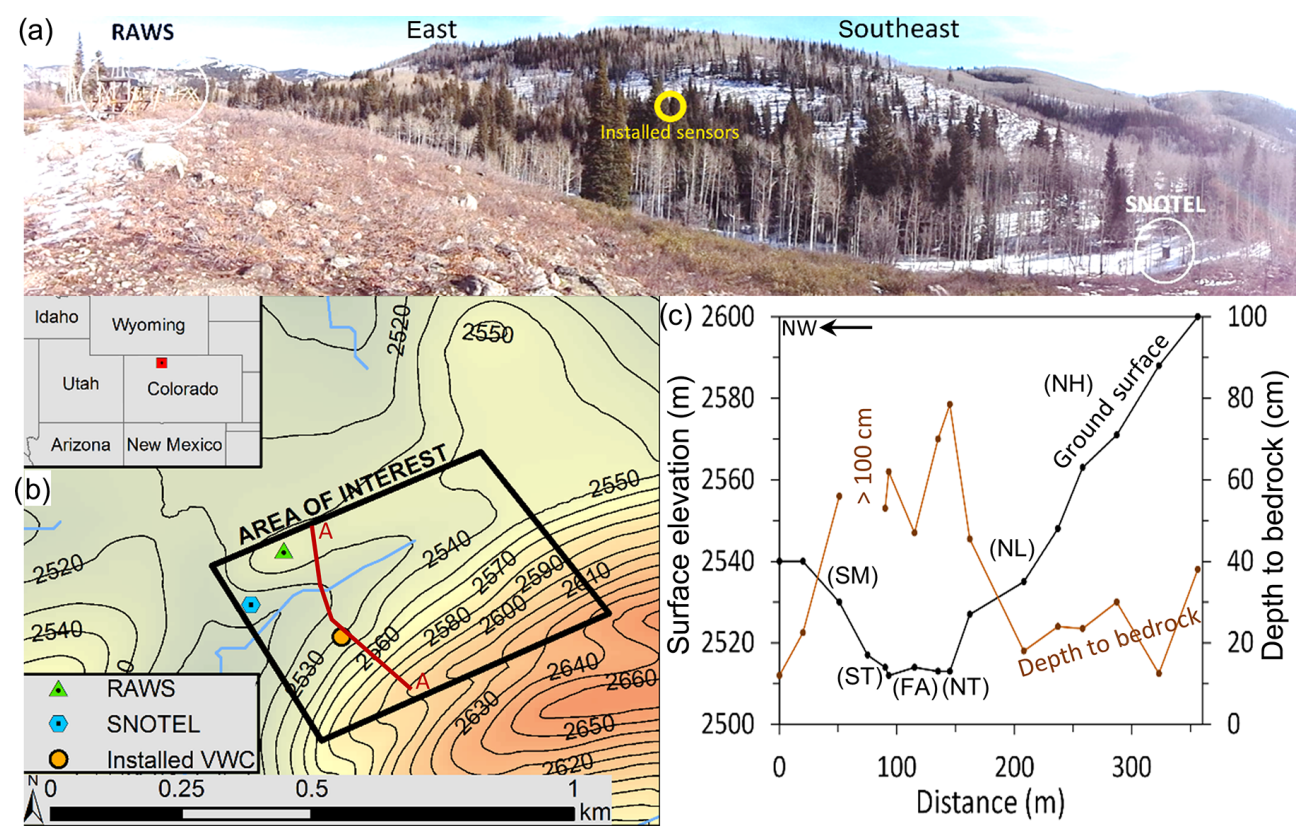

Figure 1. (a) Panoramic picture of the study area facing east to southeast. Location of photo taken to the west of Remote Automated Weather Station (RAWS) location in map (b). Locations of the RAWS, SNOTEL station, and installed soil moisture sensors are circled and labeled. (b) Map of the study site and area of interest in this investigation. $10 \mathrm{~m}$ contours are shown. (c) Cross section A-A from panel (b) showing the elevation of the ground surface and depth to bedrock using a $1 \mathrm{~m}$ long hand auger. Regions of interest are identified as middle of the south aspect hillslope (SM), toe of the south aspect slope (ST), flat aspect (FA), toe of the north aspect slope (NT), low on the north aspect slope (NL), and high on the north aspect slope (NH). All ground surface data are from $10 \mathrm{~m}$ resolution digital elevation model (USGS, 2015).

tigate if evidence preferential flow paths in snow can be observed and the effect on soil moisture through measurements of snow water equivalent (SWE) and near-surface soil moisture, (2) to observe how SWE and near-surface soil moisture vary on hillslopes relative to the toes of hillslopes and flat areas, and (3) to compare snowmelt infiltration beyond the near-surface soil between flat and sloping terrain during the entire snowmelt season.

\section{Methods}

To understand flow path development during snowmelt and the resulting distribution of soil moisture, observations of SWE and near-surface soil moisture were correlated to test the influence of topography and snow on soil moisture using Pearson's correlation coefficient, $r$, and a level of significance determined at $p$ values of 0.05 and 0.01 . Near-surface soil volumetric water content (VWC) was compared to SWE at the same location on the date of observations, SWE on the first survey date (representative of peak SWE), the change in SWE between survey dates prior to measurement, nearsurface VWC on the first survey date, and topographic slope, elevation, and northness as calculated from a $10 \mathrm{~m}$ digital elevation model (DEM; USGS, 2015). Northness is defined as the product of the cosine of aspect and the sine of slope (Molotch et al., 2005; Sexstone and Fassnacht, 2014).

\subsection{Study site}

Data were collected over a $0.2 \mathrm{~km}^{2}$ area near Dry Lake in Routt National Forest, approximately $6.5 \mathrm{~km}$ northeast of Steamboat Springs, Colorado (Fig. 1b). The elevation of measurement locations ranged from 2500 to $2600 \mathrm{~m}$ with slope angles from 1 to $30^{\circ}$ as determined from a $10 \mathrm{~m}$ DEM (USGS, 2015). The site has a mix of deciduous (aspen, Populus tremuloides) and evergreen forest (subalpine fir, Abies lasiocarpa, and Engelmann spruce, Picea engelmannii) with a majority of the vegetation growing near the small stream offering large areas of open canopy conditions (Fig. 1a) on each of the two predominant hillslopes (one south-southeast facing, and one north-northwest facing).

The soils are primarily loams with very cobbly loam dominating the south aspect slope, cobbly sandy loam on the north aspect, and loam on the flatter aspects with observations of highly organic soils in the flat northeastern section of the area at the base of the north aspect hillslope (Table 1). Depth to bedrock was estimated using a $1 \mathrm{~m}$ long hand auger at 16 locations within the study site along a transect from the top of the south aspect slope to the top of the north aspect slope (Fig. 1b), resulting in soil depths ranging from $12 \mathrm{~cm}$ to greater than $1 \mathrm{~m}$ at a single location. Soil depths tend to decrease with increasing elevation with a mean depth to bedrock of $40 \mathrm{~cm}$ and a median of $38 \mathrm{~cm}$ calculated from the 15 depths of less than $1 \mathrm{~m}$ (Fig. 1c). Sieve analyses were also 
Table 1. Percent of grain sizes by mass determined from sieve analysis of samples collected using a $\sim 200 \mathrm{~cm}^{3}$ sample at locations in the middle of the south aspect slope (SM), the toe of the south aspect slope (ST), flat aspect (FA), and low on the north aspect slope (NL). Fines are considered less than $0.074 \mathrm{~mm}$, sand is larger than fines and less than $4.75 \mathrm{~mm}$.

\begin{tabular}{lrrrr}
\hline & SM & ST & FA & NL \\
\hline Percent fines & 21 & 25 & 29 & 29 \\
Percent sand & 46 & 61 & 64 & 58 \\
Percent larger & 33 & 14 & 7 & 13 \\
\hline
\end{tabular}

conducted on six different volumetric samples of approximately $200 \mathrm{~cm}^{3}$ for near-surface soil collected from four locations (two locations sampled twice; Table 1).

For this study, regions were defined to compare observations on varying aspects and at the toes of hillslopes. Regions were defined as middle of the south aspect slope (SM), toe of the south aspect slope (ST), flat aspect (FA), toe of the north aspect slope (NT), low on the north aspect slope (NL), and high on the north aspect slope (NH; Fig. 1c).

\subsection{Spatial surveys}

Spatial surveys were conducted in 2013, 2014, and 2015. In 2013 two surveys were conducted 4 weeks apart while in 2014 and 2015 four surveys were conducted at 2-week intervals. All survey periods began during the first week of April (6 April 2013, 4 April 2014, 3 April 2015). Surveys consisted of a series of snow pits for collecting near-surface soil moisture, snow depth, and bulk SWE data. At each pit location, the first measurements taken were near-surface soil moisture using a handheld time domain reflectometer (TDR; FieldScout TDR 100; Spectrum Technologies, Inc.) to measure the VWC using $7 \mathrm{~cm}$ long prongs inserted vertically into the soil. A total of five TDR measurements were averaged across the bottom of each snow pit (approximately $1 \mathrm{~m}$ across, measurements $\sim 20 \mathrm{~cm}$ apart). Volumetric soil samples $\left(\sim 40 \mathrm{~cm}^{3}\right)$ were collected at three of the same point locations as TDR measurements in each snow pit for laboratory confirmation of VWC during surveys in 2013 and 2014. Bulk SWE measurements were collected using a plastic tube with an inner diameter of $68 \mathrm{~mm}$ and a length of $1.8 \mathrm{~m}$. A core was collected for the full depth of the snowpack when possible, and in no more than two segments when the depth of the snowpack was greater than the length of the tube. Snow cores were placed in a plastic bucket and mass measured using a digital scale with $10 \mathrm{~g}$ precision. Two cores were averaged per snow pit with additional measurements if the first two showed greater than $10 \%$ mass difference (a rare occurrence). When returning to the same locations, a new pit was dug within 1 to $2 \mathrm{~m}$ with care to avoid previously disturbed snow. Additionally, snow density profile data were collected near a Snow Telemetry (SNOTEL) site on 20 March 2013,
7 April 2013, and 20 February 2015. On 6 April 2013, 15 snow pits were measured and 6 were returned to and measured again on 4 May 2013 to capture the changes at the SM, ST, FA, NL, and NH regions (Webb and Fassnacht, 2016a). The 2014 and 2015 surveys collected data along approximate north-to-south transects perpendicular to topographic contours collecting multiple measurements in the six regions of interest. In 2014 a total of 25 snow pits were measured on 4 April and 9 of these pits were returned to in 2-week intervals through 17 May; 8 of the 9 pits were measured on 19 April (Webb and Fassnacht, 2016b). The 2015 surveys made observations at 47 snow pits on 3 April and 23 of these pits were returned to on 2-week intervals through 16 May (Webb and Fassnacht, 2016c). Snow pit measurements were then averaged at each of the regions (SM, ST, FA, NL, and $\mathrm{NH})$ for each day of observations.

\subsection{Time series data}

At the study site, there are two stations that measure meteorological variables including air temperature, relative humidity, precipitation, wind speed and direction, and solar radiation. The Dry Lake Remote Automated Weather Station (RAWS station coCDRY and National Weather Service ID 050207, raws.dri.edu) is along an exposed ridge at the top of the south aspect slope at approximately $2540 \mathrm{~m}$ elevation and has been operated by the United States Forest Service since 1985 (Fig. 1a and b). Additionally, hourly dew point and wet bulb temperature, snow depth, and SWE are measured at the Dry Lake SNOTEL (station 457, www.wcc.nrcs.usda.gov) station located approximately $120 \mathrm{~m}$ to the south-southwest of the RAWS at a lower elevation of $2510 \mathrm{~m}$ with light canopy shading (Fig. 1a) and has been operated by the Natural Resources Conservation Service since 1980 measuring SWE and precipitation. Since 2003, this SNOTEL station has additionally measured soil moisture and temperature at three depths (5, 20 , and $50 \mathrm{~cm}$ ). The RAWS and SNOTEL data provide meteorological data at two elevations and different canopy conditions within the relatively small area of interest of this study.

Snowmelt infiltration observed by the SNOTEL station is for a relatively flat location, and thus was compared to additional soil moisture and temperature instruments that were installed on the north aspect slope on 27 December 2013 at depths of $5,12.5$, and $20 \mathrm{~cm}$. The top and bottom depths match two of the SNOTEL soil moisture depths; the $12.5 \mathrm{~cm}$ depth sensor was added at mid-depth between the other sensors. Instruments installed were Decagon Devices, Inc., 5TM temperature and moisture sensors connected to a Decagon Em50 data logger. Installation in December 2013 required disturbing the snowpack and soil; thus the snowpack and soil moisture were allowed to return to near undisturbed conditions after installation, and data prior to 15 March 2014 were not included in analysis. The soil moisture sensors and data logger were calibrated prior to installation using approximately $1500 \mathrm{~cm}^{3}$ of soil collected from the study site and 


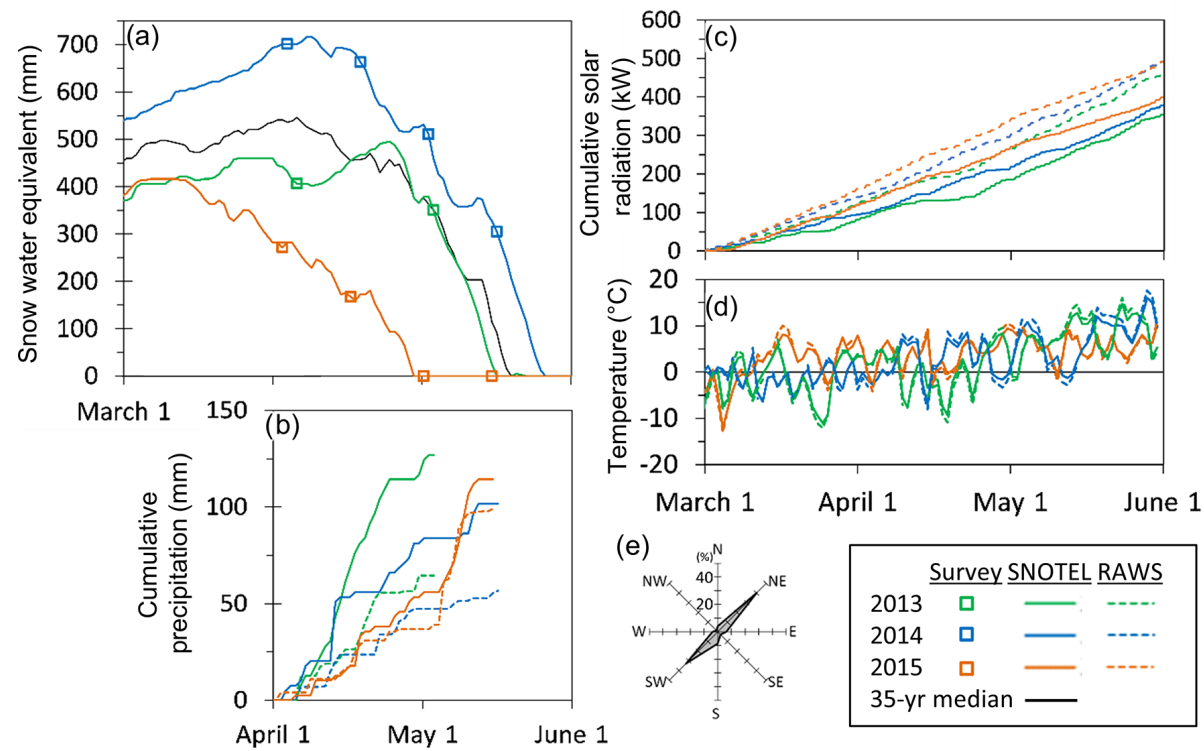

Figure 2. (a) Daily snow water equivalent (SWE) measured at the SNOTEL station each spring of the study period and the 35-year median of the station measurements, (b) cumulative precipitation occurring during the spring survey study periods of April and May as measured at the SNOTEL and RAWS site, (c) cumulative solar radiation at the SNOTEL and RAWS sites during spring, (d) mean daily temperature at the SNOTEL and RAWS sites during spring, and (e) wind rose of spring data for the three years studied at the SNOTEL site.

tamped around a sensor to a density of $1.0 \mathrm{~g} \mathrm{~cm}^{-3}$, similar to measured conditions in the field. The calibration occurred at a constant temperature of $0.5^{\circ} \mathrm{C}$ and additions of 7 to $10 \%$ VWC every 4 days. The container mass was recorded to confirm mass of soil, sensor, and water as well as the sensor reading of temperature and VWC prior to the addition of water each time. All mass recordings were at a precision of $1.0 \mathrm{~g}$ (volumetric water precision of $0.06 \%$ ) and VWC sensor recordings to $0.1 \%$.

\section{Results}

\subsection{Time series snow and meteorological data}

The three spring snowmelt seasons studied represent varying melt conditions. Average peak SWE occurs at the Dry Lake SNOTEL station on 5 April with a 35 year median peak of $570 \mathrm{~mm}$ and a mean of $590 \mathrm{~mm}$ (Fig. 2a). Peak SWE values recorded at the SNOTEL station were 495, 715, and $415 \mathrm{~mm}$ for 2013, 2014, and 2015, respectively, representing 87, 125, and $73 \%$ of the station long-term median. Peak SWE timing ranged from the earliest on 9 March in 2015, preceding the first survey by nearly 1 month, to the latest on 25 April in 2013, 19 days after the first survey (Fig. 2a). The number of days from peak SWE to no snow recorded at the SNOTEL station ranged from the fewest in 2013 of 22 days to the most in 2015 of 52 days, with each year having incremental snowfall during the melt period (Fig. 2b). Precipitation at the SNOTEL station during the survey periods was $130 \mathrm{~mm}$ for 2013 and $100 \mathrm{~mm}$ for 2014; in 2015 precipitation reached an accumulation of $115 \mathrm{~mm}$ from the date of the first survey to the last survey (Fig. 2b). The precipitation that fell during the melt period in 2015 likely included a number of rain-on-snow events due to the regular warmer than freezing temperatures in late April and May (Fig. 2d), though snow can fall at several degrees warmer than zero (Fassnacht et al., 2013). On 1 March, the snow accumulation was the same in 2013 and 2015, with approximately $40 \%$ more in 2014; the subsequent spring snowpack variability between years was a result of varying meteorological forcing conditions during March, April, and May (Fig. 2). The SNOTEL station data show air temperature during these months warmer than freezing 62,64 , and $77 \%$ of the time and cumulative solar radiation totaled 355, 380, and $400 \mathrm{~kW}$ in 2013, 2014, and 2015, respectively (Fig. 2c). Wind directions remained consistent each year during the spring months, generally from the southwest and northeast alternating diurnally between directions (Fig. 2e). The RAWS site showed slightly larger diurnal temperature fluctuations, greater cumulative solar radiation, and less precipitation during the spring snowmelt seasons relative to the SNOTEL station, though generally similar conditions were observed when comparing the two stations (Fig. 2).

These conditions resulted in snow density profiles that displayed thin melt-freeze crusts and ice lens formation (Fig. 3). It should be noted that the location of these snow pits near the SNOTEL station contains a lot of buried vegetation and large rocks causing difficulties in obtaining density measurements near the ground surface. The 2013 melt season observed the development of a higher density layer near $70 \mathrm{~cm}$ above ground that deteriorated in the time between observa- 


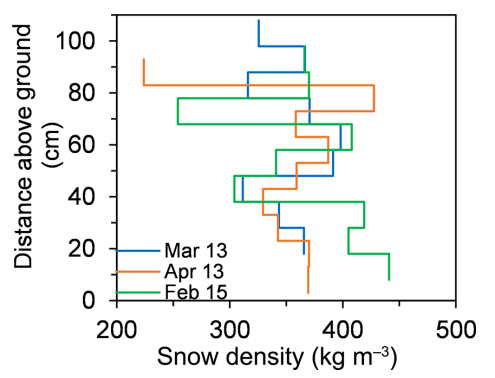

Figure 3. Observations snow density profiles on 20 March 2013, 7 April 2013, and 20 February 2015.

tions, though a higher density layer formed at $\sim 80 \mathrm{~cm}$ above ground, likely as the result of melt-freeze cycles. The February 2015 density profile showed a similar high density layer near $70 \mathrm{~cm}$ above ground, though additional higher density snow is observed closer to the ground (Fig. 3). These density profiles provide observations near peak SWE for 2013 and 2015 with average densities between 350 and $370 \mathrm{~kg} \mathrm{~m}^{-3}$ during the varying meteorological conditions each year, respectively.

\subsection{Spatial surveys}

The variable meteorological influences on the snowpack and soil moisture was observed through the spatial surveys. Surveys conducted in 2013 and 2014 occurred while a measurable snowpack was still observed at the SNOTEL station for all survey dates, whereas in 2015 the SNOTEL station measured zero snow for the final two of the four surveys resulting in variable conditions for SWE and VWC measurements each year. In 2013 all north aspect locations increased in SWE between surveys with the largest increase occurring at the toe of the north aspect slope (NT, $160 \mathrm{~mm}$ ) and the smallest increase high on the slope (NH, $20 \mathrm{~mm}$; Fig. 4bi). SWE also increased at the toe of the south aspect slope (ST, $90 \mathrm{~mm}$ ) and decreased in the middle of the south-facing slope (SM; Fig. 4bi). In 2014 a similar pattern was observed of increases in SWE at the toes of each slope (ST and NT) and lesser increases on the north-facing hillslope (Fig. 4biii), though low on the slope one pit location decreased in SWE and another remained the same (Fig. 4aiii). Increases in SWE occurred early in the melt period for 2013 and 2014, whereas the early melt period was not observed in 2015 due to the early peak accumulation. After the initial increase in SWE for some locations during the first melt period observed (MP1), all locations decreased in SWE for the two following melt periods (Fig. 4b). In 2015, SWE did not change during MP-1 at NT and ST regions, while it decreased at the four other locations (Fig. 4bv). This is less of a change in SWE for regions that showed large increases in 2013 and 2014. At the toes of each slope in 2014, the increase in SWE during the first melt period was larger than the decrease in the following two melt periods combined (Fig. 4). In 2015, only two measurement locations had snow during the final survey (16 May) and precipitation influenced observations (discussed later).

In 2013 and 2014 evidence of lateral flow in the form of frozen ice "veins" immediately above the snow-soil interface (SSI) were observed during the early melt season surveys (Fig. 5). These were observed on the north aspect (NL and $\mathrm{NH}$ ) and at the toe of the north aspect slope (NT) only and appeared to be continuous, though continuity was only confirmed for 3 to $4 \mathrm{~m}$ based on excavation. The occurrence of this phenomenon was in the direction of the hillslope fall line and on ground that was not supersaturated. These ice veins were not observed in 2015 though they may have occurred prior to our observations since the early melt season was not observed that year. Ice lenses were observed in the snow stratigraphy on the north hill slope in about one-third of the observed locations on the hillslope. Also qualitatively observed was the relative density of snow in each pit in 2014. On the north aspect slope, snow density tended to decrease with height above the SSI, with heavy wetter snow remaining in the bottom of the snowpack in the form of saturated snow at the bottom of each pit. These saturated snow layers increased in depth downslope and were only observed at the bottom of the snowpack directly above the SSI.

The near-surface soil VWC during all surveys varied from mean values of 15 to $85 \%$ (Fig. 4). The maximum soil moisture consistently occurred at the toe of the north aspect hillslope (NT) in the highly organic soil. The soil at this location was also observed to be supersaturated during a single survey on 19 April 2014 (resulting in the $85 \%$ VWC and surface ponding; Fig. 4bii). The near-surface soil VWC showed variable observations of increasing and decreasing soil moisture beneath a melting snowpack with relatively larger decreases immediately following snow disappearance (Fig. 4a).

The 2015 surveys resulted in the largest variability of measurements each survey for both SWE and near-surface VWC (Fig. 4c). The early peak accumulation resulted in only two measurement locations with snow for all four survey dates. However, as with previous years, near-surface VWC decreased noticeably after the disappearance of snow for all locations with some increases due to rain events (Fig. 4b).

\subsection{Spatial correlation}

The topographic parameters of elevation, slope, and northness showed mostly low correlations to near-surface VWC during observations and little significance at the 0.05 level (Table 2). The only topographic parameter that resulted in a Pearson's $r$ value of magnitude larger than 0.5 was slope, occurring later in the 2014 observation period. The only topographic parameter that showed any significance was northness on 16 May 2015, when soil had been exposed to the atmosphere from loss of snow for $93 \%$ of measurement locations. 
(a) Measured values

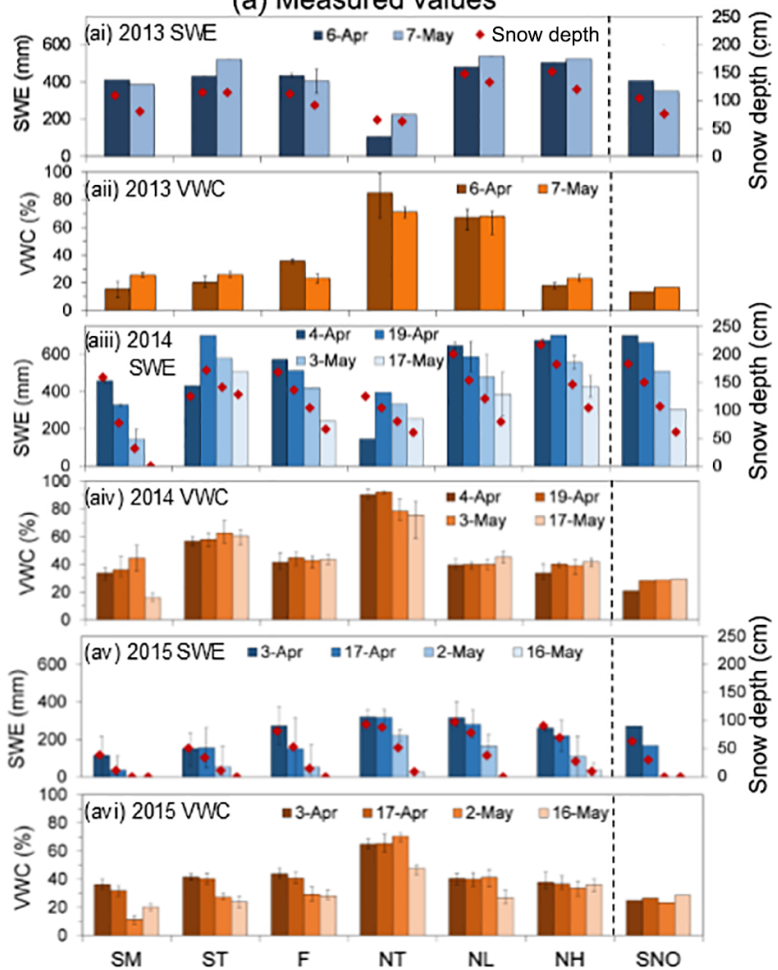

(b) Changes in measured values

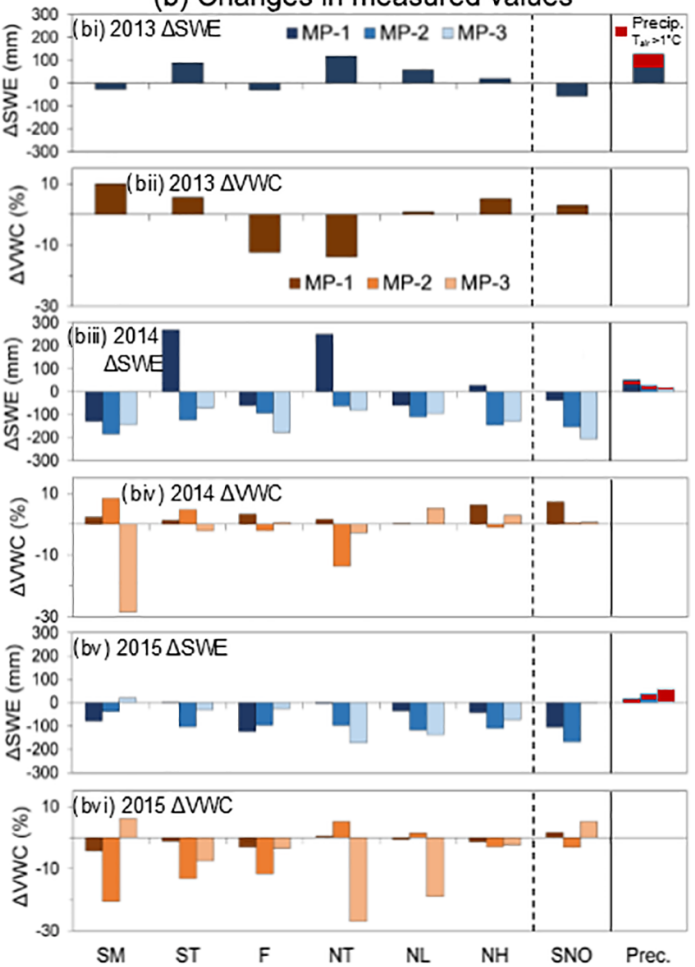

Figure 4. Observations of (a) measured values for snow water equivalent (SWE) and near-surface soil volumetric water content (VWC) and (b) changes in measured values between survey dates for regions of interest: middle of the south aspect hillslope (SM), toe of the south aspect slope (ST), flat aspect (FA), toe of the north aspect slope (NT), low on the north aspect slope (NL), and high on the north aspect slope (NH). Also included are observed values at the SNOTEL site (SNO) that include SWE and precipitation (Precip.) with precipitation that fell when air temperature $\left(T_{\text {air }}\right)$ was greater than $1^{\circ} \mathrm{C}$ shown in red. Figure panels display (i) $2013 \mathrm{SWE}$, (ii) $2013 \mathrm{VWC}$, (iii) $2014 \mathrm{SWE}$, (iv) 2014 VWC, (v) 2015 SWE, and (vi) 2015 VWC. Changes are shown for melt period 1 (MP-1) between the first two surveys, melt period 2 (MP-2) between the second and third surveys, and melt period 3 (MP-3) between the third and fourth surveys. Each melt period is 14-15 days with the exception of in 2013, which was 28 days. Error bars indicate total range of measurements at locations.

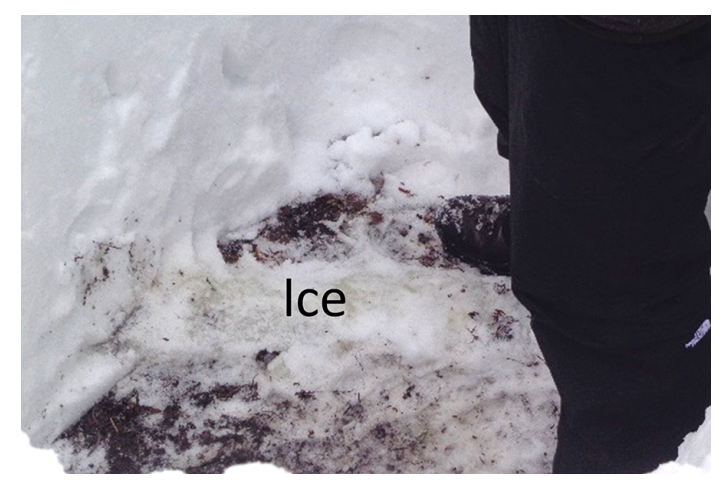

Figure 5. Picture of frozen ice "vein" observed at the snow-soil interface (SSI) providing evidence of lateral flow of meltwater occurring within the snowpack. Foot shown for scale.

Measurement locations were also tested for correlation of hydrologic variables to near-surface VWC that included SWE, $\triangle$ SWE, first-measured SWE, and first-measured VWC. These variables showed higher correlations and more occurrences of significance at the 0.05 and 0.01 level relative to topographic parameters (Table 2). The highest Pearson's $r$ values of all variables to near-surface VWC was that of the first-measured near-surface VWC that are positive with all but one correlation being significant at the 0.01 level. Pearson's $r$ values tend to decrease in magnitude for this variable as time from the first survey increases (Table 2).

The correlation of SWE variables to near-surface VWC were inconsistent in strength, direction, and significance with a lot of variability each survey. The mostly negative correlations for near-surface VWC to $\triangle$ SWE indicate that in 2013 and 2014, locations with lesser changes in SWE had higher near-surface VWC, though this was significant at the 0.05 level on 19 April 2014 only (Table 2). The similar negative correlation and magnitudes of near-surface VWC to firstmeasured SWE show that in 2013 and 2014, areas that had less SWE during the first survey tended to have higher measured VWC at later dates, significant at the 0.05 level on 19 April 2014, and at the 0.01 level on 3 May 2014 (Table 2). 
Table 2. Results of pattern analysis of near-surface soil moisture measurements based on slope angle, northness (North.), elevation (Elev.), SWE, change in SWE ( $\triangle \mathrm{SWE}$ ), SWE on first survey of the year, and near-surface soil moisture (VWC) on first survey of the year. Significant values are shown in italic; figures in bold have $p$ values of less than 0.05 and those underlined have $p$ values of less than 0.01 .

\begin{tabular}{llrrrrrrr}
\hline & & Slope & North. & Elev. & SWE & $\Delta$ SWE & First SWE & First VWC \\
\hline 2013 & 6 Apr & 0.19 & 0.327 & 0.02 & $\mathbf{0 . 5 2}$ & - & - & - \\
& 4 May & 0.12 & 0.090 & 0.12 & -0.25 & -0.68 & -0.57 & $\underline{\mathbf{0 . 9 2}}$ \\
\hline \multirow{2}{*}{2014} & 4 Apr & -0.21 & 0.006 & -0.12 & -0.36 & - & - & - \\
& 19 Apr & -0.40 & 0.070 & 0.03 & -0.08 & $-\boldsymbol{0 . 8 2}$ & $\mathbf{- 0 . 8 3}$ & $\underline{\boldsymbol{0 . 9 9}}$ \\
& 3 May & -0.63 & 0.410 & -0.02 & 0.30 & -0.38 & $-\underline{\boldsymbol{0 . 8 9}}$ & $\underline{\boldsymbol{0 . 9 5}}$ \\
& 17 May & 0.57 & 0.494 & -0.40 & 0.62 & -0.48 & -0.39 & $\underline{\mathbf{0 . 8 2}}$ \\
\hline 2015 & 3 Apr & -0.18 & 0.181 & -0.22 & 0.12 & - & - & - \\
& 17 Apr & -0.08 & 0.262 & -0.01 & $\underline{\mathbf{0 . 5 6}}$ & -0.09 & $\mathbf{0 . 4 7}$ & $\underline{\mathbf{0 . 9 5}}$ \\
& 2 May & 0.11 & 0.015 & 0.26 & $\underline{\mathbf{0 . 8 7}}$ & 0.36 & $\underline{\mathbf{0 . 5 6}}$ & $\underline{\mathbf{0 . 8 0}}$ \\
& 16 May & 0.06 & $\underline{\mathbf{0 . 4 1 7}}$ & 0.26 & $\mathbf{0 . 4 6}$ & $\mathbf{0 . 5 0}$ & 0.15 & $\mathbf{0 . 4 8}$ \\
\hline
\end{tabular}

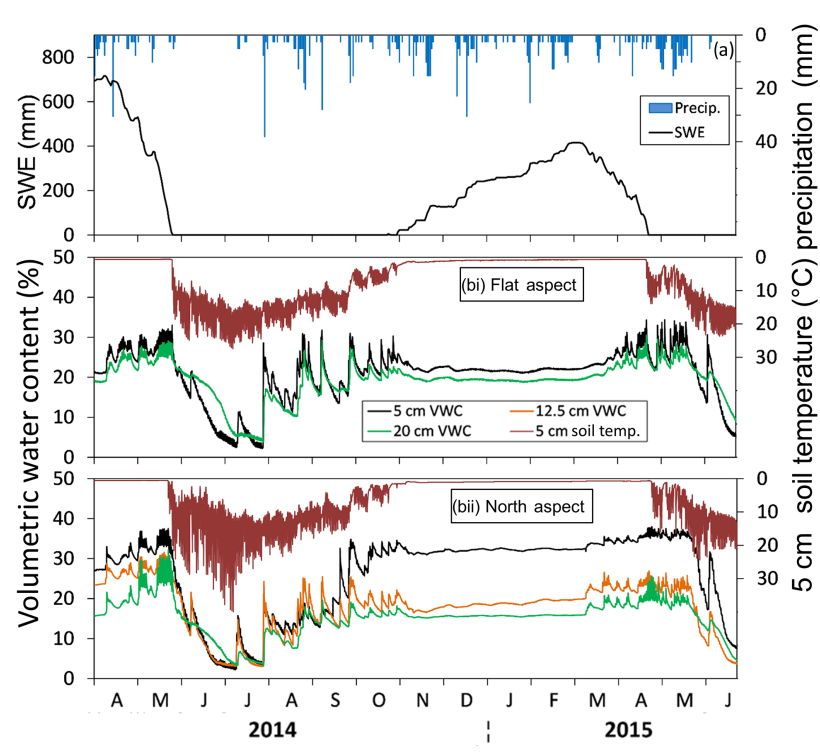

Figure 6. (a) Daily snow water equivalent (SWE) and precipitation recorded at the Dry Lake SNOTEL station and (b) the hourly soil volumetric water content (VWC) and $5 \mathrm{~cm}$ deep temperature at (bi) the flat SNOTEL site and (bii) the installed sensors on the north aspect slope.

\subsection{VWC time series data}

Soil moisture and temperature sensors clearly show the diurnal fluctuation of VWC from snowmelt infiltration across the SSI and the fluctuation in soil temperature as snow disappears (Fig. 6). Soil temperatures at $5 \mathrm{~cm}$ depth remain between 0 and $1{ }^{\circ} \mathrm{C}$ throughout winter, and temperatures begin to fluctuate in the soil at approximately the same time of snow disappearance (Fig. 6). This temporal pattern occurs at both the SNOTEL station and on the north aspect slope. These locations also show relatively quick drying after snow disappearance in 2014 and slower drying as a result of rain in 2015. However, there is more drying between rain events on the flat aspect compared to the north aspect slope (Fig. 6b). At the flat aspect SNOTEL station, the VWC sensors at 5 and $20 \mathrm{~cm}$ depths follow a similar temporal pattern remaining within $5 \%$ of each other the entire winter season, indicating snowmelt infiltrating and wetting the soil at $20 \mathrm{~cm}$ depths and a higher relative saturation in the entire vadose zone (Fig. 6bi). Beneath the snowpack and during melt, the north aspect hillslope VWC sensors show a difference of approximately 15-20\% with more similar VWC observed during summer and fall rain events (Fig. 6bii). This is more pronounced in 2015 where the 2014 season may have been impacted by the mid-winter installation of the sensors. The lower VWC values at $20 \mathrm{~cm}$ depth show less relative saturation in the vadose zone on the north-facing slope (Fig. 6bii) compared to flat terrain (Fig. 6bi).

Rain events that occurred prior to soil moisture drying in May 2015 resulted in infiltration excess overland flow due to high intensity precipitation. These events occurred prior to new vegetation becoming established on the hillslope. Evidence of overland flow was observed during the 16 May 2015 survey when most of the snow had disappeared on all hill slopes and the dead grasses from the previous summer were lying flat on the ground and vegetation litter piled up in the downslope direction; this was not the observed state of the dead grasses and litter in snow-free areas during the previous survey on 2 May. During the overland flow event(s), differences in VWC measurements at 5, 12.5, and $20 \mathrm{~cm}$ deep sensors on the north aspect slope are similar to what is observed during the snowmelt season and are different than that observed during rain events during the summer and fall (Fig. 6bii). However, the flat aspect VWC sensors displayed similar patterns during nearly all rainfall or snowmelt events (Fig. 6bi). These observations indicate that less snowmelt infiltrates to $20 \mathrm{~cm}$ depth on the north-facing slope relative to the flat aspect (Fig. 6b) and that snowmelt water is flowing downslope near the SSI (Fig. 5). 


\section{Discussion}

The multiple years of observation at a subalpine location with a deep seasonally persistent snowpack offers analysis of SWE and near-surface VWC patterns that have previously been limited to lower elevations near the rain-snow transition zone (C. J. Williams et al., 2009) and higher elevations in an alpine environment (Litaor et al., 2008). In this study, the only topographic parameter that displayed any significance on the near-surface soil moisture at the 0.05 level was northness and this appeared to increase in significance and strength with time, indicating that it is likely more related to the presence or absence of snow and influences from rain (Table 2). However, infiltration of snowmelt beneath the near surface to $20 \mathrm{~cm}$ depth was influenced by slope with more infiltration wetting the soils at $20 \mathrm{~cm}$ depth on the flat aspect and lesser wetting at this depth on the north aspect in the early melt season (Fig. 6b) where observations of ice veins and saturated layers of snow were made at the SSI (Fig. 5). The soils on the south aspect slope are generally coarser than the north or flat aspects (Table 1), suggesting that soil water retention is higher on north aspects (Geroy et al., 2011). This was reflected with the north aspect soils often having similar and/or higher water contents than south aspect soils, both with and without the presence of a snowpack (Fig. 4, SM vs. $\mathrm{NL}$ and $\mathrm{NH}$ ). As the snowpack melts the shallow subsurface VWC displays clear diurnal fluctuations (Fig. 6b). The locations that were wet relative to other locations during the first survey remained as such for all following surveys when snow persistently covered the study area, comparing well to the study by C. J. Williams et al. (2009) at a smaller scale and beneath a shallow snowpack near the rain-snow transition zone at a lower elevation. However, in contrast to C. J. Williams et al. (2009), near-surface VWC showed a negative correlation to the first-measured SWE (representative of peak) in 2013 and 2014. This negative correlation indicates that locations with lower peak SWE (during the first survey of the season) tend to have greater VWC at the later surveys. This is the result of the shallower snowpacks during the first survey being near the bottom of the slopes and in the flat terrain influenced by canopy interception (Fig. 1a), and the subsequent melt flows downslope at the SSI towards these locations increasing both SWE and near-surface VWC during the following surveys (Fig. 4). However, in 2015, a relatively low snow year, results agreed with C. J. Williams et al. (2009) of higher near-surface VWC at locations that accumulated more snow, indicating the amount of snowfall is also important to these processes. During low snow years, areas where snow persists longer will result in a longer influence on nearsurface soil moisture. Near-surface VWC will additionally depend on variability in soil parameters such as soil water retention, with higher moisture retention from finer soil particles, similar to the north aspect slope, affecting the infiltration or lateral flow of meltwater at the SSI when on a slope.
Meltwater flowing downslope near the SSI on the north aspect hillslope is shown by the increases in SWE at locations on and at the toe of the hillslope (Fig. 4), the frozen ice veins observed in 2013 and 2014 early melt seasons (Fig. 5), less infiltration to $20 \mathrm{~cm}$ depth on the slope (Fig. 6), similarities in soil moisture between snowmelt and overland flow rain events, and the observations of snow density and wetness increasing with depth downslope in each north aspect snow pit. For the south aspect slope, the increases in SWE at the ST locations were similar to observed precipitation in 2013 and an increase in snow depth for 2014. The south aspect slope may have meltwater flowing downslope near the SSI, though to a lesser extent than the north-facing slope and less apparent. The movement of water across layer interfaces has been shown within a snowpack (Williams et al., 2000, 2010; Liu et al., 2004) and at the SSI (Eiriksson et al., 2013), with evidence of the latter being observed in this study (Fig. 5). This phenomenon will depend on soil parameters, snowpack layer characteristics, slope angle, and the rate that meltwater is percolating through the snowpack. These factors will determine if an interface acts as a permeability barrier, similar to a soil drain, or as a capillary barrier (Avanzi et al., 2016; Webb, 1997; Webb et al., 2018). The primary reasons for lateral flow through the snowpack on the north-facing slope is a result of the slower melt rates and hydraulic conductivity of the soil. When capillary barriers occur, the diversion length will be controlled by the hydraulic properties of the media, slope of the interface (steeper slope increases diversion length), and infiltration rate (slower infiltration rate increases diversion length; Webb, 1997; Webb et al., 2018). It is also possible for lateral flow to be caused by barriers within a layered snowpack well above the SSI, though the large saturated layer of snow was observed only at the SSI in all north aspect snow pits, showing this is where the bulk of the lateral flow occurs. Further testing and field experiments are necessary to quantify the influence of varying slope and soil parameters on these processes in and below a snowpack. Our study shows preferential flow paths during snowmelt on the north-facing slope that are similar to an alpine catchment with water flowing through the snowpack downslope (Liu et al., 2004; Williams et al., 2000), during rain on snow events at lower-elevation sites (Eiriksson et al., 2013), and observations in a coastal climate (Kattelmann and Dozier, 1999). These processes can be combined into a conceptualization of the northern aspect slope having meltwater flow paths near the SSI downslope and the southern aspect slope having more infiltration into the soil (Fig. 7).

As hydraulic barriers form and promote flow paths to develop within the snowpack such as on the north aspect slope, the timing of runoff at the hillslope scale can change dramatically. Snow has been shown to have a hydraulic conductivity orders of magnitude greater than common soils (Yamaguchi et al., 2010; Domine et al., 2013) and will thus be important for hydrologic modeling and flood prediction from snowmelt runoff. From a groundwater recharge perspective, 
(SM) Most snowmelt infiltrates into soil

(ST) Wetting front across soil-bedrock interface towards stream

(FA) Wetting front across soil-bedrock interface towards stream, some saturated overland flow

(NT) Water table rises above soil surface, wetting front moves towards stream

$(\mathrm{NL}, \mathrm{NH})$ Snowmelt is laterally diverted at the snow-soil interface with some infiltration

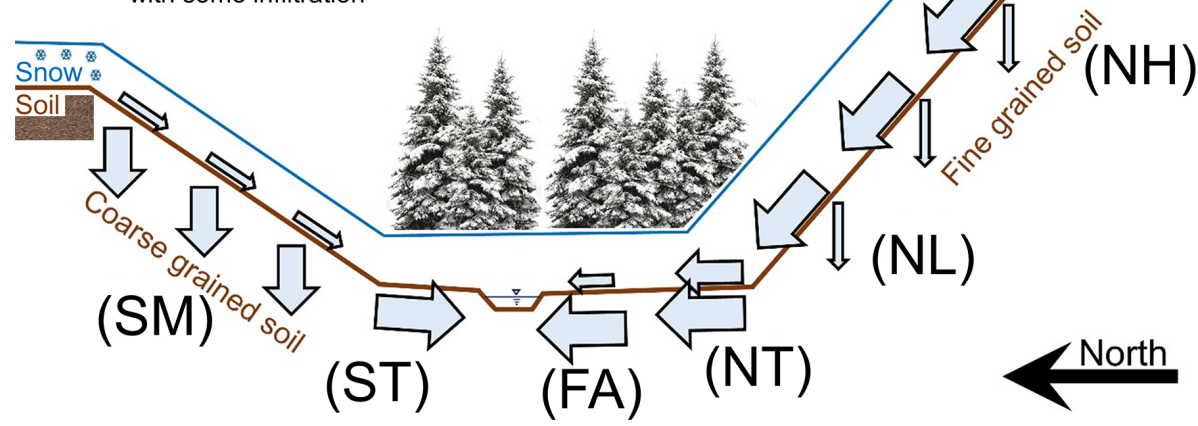

Figure 7. Conceptual model of flow paths that develop during early spring snowmelt at the south aspect hillslope (SM), toe of south aspect slope (ST), flat aspect (FA), toe of north aspect slope (NT), low on the north aspect hillslope (NL), and high on the north aspect hillslope (NH).

much of the hydraulic gradients driving subsurface flow will be occurring at the base of the north aspect hillslope in this study area due to the lateral flow of water through the snowpack, and soil moisture sensors on the slope will only account for a fraction of the total meltwater as flow paths bypass sensor profiles. Also, at the base of the hillslope (NT) the snowpack can increase in bulk SWE by up to $250 \mathrm{~mm}$ (from 146 to $396 \mathrm{~mm}$; Fig. 4aiii), displaying the increased storage capacity of a location by the porosity of the snow. This will result in areas of focused recharge and variable infiltration in the subsurface as observed in other subalpine regions (Webb et al., 2015). However, hillslopes can still display a more classical conceptualization of snowmelt infiltration uniformly and traveling across the soil-bedrock interface to recharge groundwater resources and generate streamflow as on the south aspect slope (Fig. 7).

In order to estimate the ratio of lateral flow to infiltration on the north aspect slope, an energy budget calculation was conducted. The energy budget was calculated assuming an isothermal snowpack on the date of peak SWE observed at the SNOTEL station and utilizing the SNOTEL-measured air temperature, relative humidity, wind speed, precipitation, and shortwave radiation. Fraction of cloud cover was estimated from comparing clear-sky expected shortwave radiation based on latitude and time of year to observed solar radiation at the RAWS location based on Fassnacht et al. (2001). This estimated energy budget was calibrated through adjustments to the longwave radiation component to match average SWE losses at the SNOTEL station. The north aspect energy budget was then estimated through altering the shortwave radiation component by a factor of 0.7 based on average slope and aspect for the month of April. This resulted in the northfacing hillslope having an approximated average melt rate of
0.6 that of the SNOTEL station. Using the $10 \mathrm{~m}$ DEM we estimated average contributing areas for the snow pit locations on the north-facing slope. We then used the changes in SWE and observed precipitation to estimate the contribution of lateral flow for the 2 -week periods between observations. Given the observed increases in SWE on the north-facing hillslope this results in a minimum of $4 \%$ of melt traveling laterally above the SSI to produce the observed increases in SWE. The $4 \%$ is water that flows downslope above the SSI and remains in the snowpack. Therefore, the percentage may be larger when considering drainage from the snowpack after flowing laterally. Although $4 \%$ of melt flowing downslope within a snowpack is a low number, it accumulates along the $250 \mathrm{~m}$ hillslope to increase the SWE at the toe of the slope the most. The $170 \%$ increase in SWE at NT observed in 2014 (Fig. 4) is likely a result of water flowing both above the SSI and below it causing the water table to rise, though the increases in SWE at NL can be attributed to flow above the SSI. Estimating SWE from depth measurements alone in this area will be inaccurate when not considering the effect of preferential flow paths within the snowpack and the resulting effects on snow density.

Preferential flow paths and aspect controls during snowmelt have been observed at lower elevations. At a different site in Colorado, near the rain-snow transition zone, the intermittent snowpack on south aspects displayed matrix flow, whereas north aspects displayed preferential flow paths through the soil (Hinckley et al., 2014). These results are similar to those observed in the present study during the 2015 snowmelt, while the 2013 and 2014 seasons displayed what can be interpreted as lesser melt rates on the north slopes than the south slopes due to temperature and radiation differences (Fig. 2c and d) that result in the preferential flow paths 
near the SSI. In this study, the north aspect slope displays preferential flow paths early in the snowmelt season similar to alpine regions (Liu et al., 2004; Williams et al., 2015) that can transport a large amount of water relative to the following melt periods (Fig. 4ai and bi). Flow paths then transition to more uniform melting and less preferential flow as the melt season progresses. In 2015, this may have also occurred prior to our observation period, though this is uncertain. The south aspect slope is similar to slopes at lower elevations near the rain-snow transition zone (Eiriksson et al., 2013; Hinckley et al., 2014) that display uniform melt and matrix type of flow with small amounts of water diversion at the SSI.

In 2014, the large increase in SWE at the toe of the north aspect slope (NT) is from the lateral flow of water in snow and the rising of the water table above the soil surface (Fig. 4bi) as evidenced through observations of a deep saturated layer at the bottom of the snowpack and saturated soils. This is a result of snowmelt primarily influencing the top $10 \mathrm{~cm}$ of soil on the slope (Blankinship et al., 2014) and water flowing downslope near the SSI decreasing the travel time of water on the hillslope and increasing connectivity at the toe of the hillslope and water table similar to observations in the northern Rocky Mountains (Jencso et el., 2009). Some locations on the north aspect slope in 2014 remained consistent in the amount of bulk SWE while other locations on the hillslope decreased in SWE due to preferential flow paths causing non-uniform flow across the hillslope (Fig. 5). The 2015 observations show the result of rain-on-snow events occurring that are known to produce lateral flow within snowpacks (Eiriksson et al., 2013). The major difference of 2015 is earlier peak SWE and melt season along with increased solar radiation and warmer temperatures (Fig. 2). It is possible that preferential flow paths caused more lateral diversions earlier in the season; however no evidence of this was observed in our study. Future hillslope-scale investigations of these phenomena may benefit from larger-scale runoff lysimeter studies similar to Eiriksson et al. (2013) and observing the entire melt season to capture peak SWE processes in low years.

In flat terrain, snowmelt patterns are known to have correlation lengths of 5 to $7 \mathrm{~m}$ in alpine environments (Sommerfeld et al., 1994; Williams et al., 1999) and 2 to $4 \mathrm{~m}$ in a subalpine environments (Webb, 2017). These correlation lengths are less than the distances between measurement locations in this study. However, these correlation lengths are explained by flow across snow layer interfaces and snow topography in flat terrain (Sommerfeld et al., 1994; Williams et al., 1999, 2010). Increasing the topographic slope will thus increase the correlation lengths as the snow layer interfaces tilt with the slope of the ground (Webb, 1997; Webb et al., 2018). This study shows that the resulting correlation lengths in complex terrain with steep slopes can increase towards the scale of the terrain variability and result in increases in SWE at the toes of hillslopes. Further investigations are necessary to determine the scale that water may flow through snow or at the SSI on steep slopes. Future studies will benefit from the use of numerous soil moisture sensors to obtain time series data of soil VWC at multiple locations within a watershed to observe the variable infiltration characteristics during snowmelt that are difficult to detect from the near-surface soil moisture alone.

When considering dynamic hydrologic processes that occur during spring snowmelt in subalpine headwater catchments, it is important to consider the variable flow paths that develop based on factors such as slope, aspect, soil parameters, and snowpack characteristics to move beyond singlepoint measurements and one-dimensional assumptions. The toe of a hillslope is an important location to observe and estimate the amount of hillslope runoff occurring near or above the SSI relative to flow through the soil in future investigations. Future studies will benefit from considering the snowpack as an extension of the vadose zone during spring snowmelt due to the variable saturated flow that occurs.

\section{Conclusions}

The observations of this study occurred during abovenormal, relatively normal, and below-normal snow seasons capturing bulk SWE and soil VWC variability in space and time during spring snowmelt with varying meteorological forcing conditions, including rain-on-snow events in 2015. Evidence was presented of preferential meltwater flow paths at the snow-soil interface on the north aspect hillslope during early snowmelt. The effect of these preferential flow paths were observed in changes in SWE and infiltration in the shallow subsurface at $20 \mathrm{~cm}$ depth, but not observed in the nearsurface soil moisture. Near-surface soil moisture is correlated the strongest with soil moisture measured during the first survey relative to other topographic parameters or hydrologic variables. Infiltration beyond the near surface occurred more on flat terrain when compared to sloped conditions during the entire snowmelt season, resulting in greater relative saturation in the shallow subsurface in the flat area.

The snowpack is a porous medium that is an extension of the vadose zone and increases the water storage capacity of a region within a watershed. Water flowing downslope near the snow-soil interface increased SWE at the toe of the north aspect hillslope by as much as $250 \mathrm{~mm}(170 \%)$, which additionally affects the soil moisture at the toe of the slope. This is a result of a minimum of $4 \%$ meltwater being directed downslope through the snowpack rather than infiltrating. The south aspect hillslope did not display evidence of this phenomenon. The differences in flow path development on the two opposite-facing hillslopes are due to differences in soil, snowpack characteristics, slope and aspect, and snowmelt rates as a result of meteorological forcing variability. The formation of hydraulic barriers at the snowsoil interface will be dependent upon the snow characteristics, soil parameters, and meteorological conditions during melt. During 2015, when a relatively low peak SWE occurred 
early and rain-on-snow events were observed, the variability of snow and soil moisture increased, displaying the connection and interactions between snow and soil moisture. Results from this study show that the snow acts as an extension of the vadose zone during spring snowmelt, and future investigations will benefit from studying both the snow and soil together.

Data availability. Data are available online through the data publisher Pangaea and the following URLs: https://doi.org/10.1594/PANGAEA.864253, https://doi.org/10.1594/PANGAEA.864254, and doi10.1594/PANGAEA.864255 (Webb and Fassnacht, 2016a, b, c).

Competing interests. The authors declare that they have no conflict of interest.

Acknowledgements. The authors would like to acknowledge multiple people that assisted with the work that is presented in this paper. The Colorado Ground Water Association provided financial assistance through the Harlan Erker Memorial Scholarship that was used to purchase the soil moisture and temperature sensors and data logger. The Colorado State University snow hydrology field methods course (WR575) provided an abundance of field work assistance with additional volunteers from the Fassnacht snow laboratory, and Sarah Schmeer was a helpful field assistant on a number of surveys. The Routt National Forest United States Forest Service was very helpful and provided valuable assistance for the research permitting process. Additionally, Jorge Ramirez and Jeffrey Niemann and two anonymous reviewers provided feedback on an earlier version of the manuscript that greatly improved the quality of this work. The authors express great appreciation for all those involved in the presented work.

Edited by: Valentina Radic

Reviewed by: two anonymous referees

\section{References}

Adam, J. C., Hamlet, A. F., and Lettenmaier, D. P.: Implications of global climate change for snowmelt hydrology in the twenty-first century, Hydrol. Process., 23, 962-972, https://doi.org/10.1002/hyp.7201, 2009.

Adams, E., Slaughter, A., McKittrick, L., and Miller, D.: Local terrain-topography and thermal-properties influence on energy and mass balance of a snow cover, Ann. Glaciol., 52, 169-175, 2011.

Avanzi, F., Hirashima, H., Yamaguchi, S., Katsushima, T., and De Michele, C.: Observations of capillary barriers and preferential flow in layered snow during cold laboratory experiments, The Cryosphere, 10, 2013-2026, https://doi.org/10.5194/tc-10-20132016, 2016.
Bales, R. C., Molotch, N. P., Painter, T. H., Dettinger, M. D., Rice, R., and Dozier, J.: Mountain hydrology of the western United States, Water Resour. Res., 42, W08432, https://doi.org/10.1029/2005wr004387, 2006.

Bales, R. C., Hopmans, J. W., O’Geen, A. T., Meadows, M., Hartsough, P. C., Kirchner, P., Hunsaker, C. T., and Beaudette, D.: Soil moisture response to snowmelt and rainfall in a Sierra Nevada mixed-conifer forest, Vadose Zone J., 10, 786, https://doi.org/10.2136/vzj2011.0001, 2011.

Blankinship, J. C., Meadows, M. W., Lucas, R. G., and Hart, S. C.: Snowmelt timing alters shallow but not deep soil moisture in the Sierra Nevada, Water Resour. Res., 50, 1448-1456, https://doi.org/10.1002/2013wr014541, 2014.

Clilverd, H. M., White, D. M., Tidwell, A. C., and Rawlins, M. A.: Sensitivity of northern groundwater recharge to climate change: a case study in northwest Alaska, J. Am. Water Resour. As., 47, 1228-1240, https://doi.org/10.1111/j.17521688.2011.00569.x, 2011.

Clow, D. W.: Changes in the timing of snowmelt and streamflow in Colorado: a response to recent warming, J. Climate, 23, 22932306, https://doi.org/10.1175/2009jcli2951.1, 2010.

Colbeck, S.: Water-flow through heterogeneous snow, Cold Reg. Sci. Technol., 1, 37-45, https://doi.org/10.1016/0165232X(79)90017-X, 1979.

Domine, F., Morin, S., Brun, E., Lafaysse, M., and Carmagnola, C. M.: Seasonal evolution of snow permeability under equi-temperature and temperature-gradient conditions, The Cryosphere, 7, 1915-1929, https://doi.org/10.5194/tc-7-19152013, 2013.

Eiriksson, D., Whitson, M., Luce, C. H., Marshall, H. P., Bradford, J., Benner, S. G., Black, T., Hetrick, H., and McNamara, J. P.: An evaluation of the hydrologic relevance of lateral flow in snow at hillslope and catchment scales, Hydrol. Process., 27, 640-654, https://doi.org/10.1002/hyp.9666, 2013.

Elder, K., Cline, D., Liston, G. E., and Armstrong, R.: NASA Cold Land Processes Experiment (CLPX 2002/03): field measurements of snowpack properties and soil moisture, J. Hydrometeorol., 10, 320-329, https://doi.org/10.1175/2008jhm877.1, 2009.

Fassnacht, S. R., Snelgrove, K. R., and Soulis, E. D.: Daytime longwave radiation approximation for physical hydrological modelling of snowmelt: a case study of southwestern Ontario, in: Proceedings of the Sixth IAHS Scientific Assembly at Maastricht, Netherlands, 2001.

Fassnacht, S. R., Cherry, M. L., Venable, N. B. H., and Saavedra, F.: Snow and albedo climate change impacts across the United States Northern Great Plains, The Cryosphere, 10, 329 339, https://doi.org/10.5194/tc-10-329-2016, 2016.

Fassnacht, S. R., Venable, N. B. H., Khishigbayer, J., and Cherry, M. L.: The probability of precipitation as snow derived from daily air temperature for high elevation areas of Colorado, United States, cold and mountain region hydrological systems under climate change: towards improved projections, in: Proceedings of symposium H02, IAHS-IAPSO-IASPEI Assembly, Gothenburd, Sweden, July 2013, IAHS, 360, 65-70, 2013.

French, H. and Binley, A.: Snowmelt infiltration: monitoring temporal and spatial variability using timelapse electrical resistivity, J. Hydrol., 297, 174-186, https://doi.org/10.1016/j.jhydrol.2004.04.005, 2004. 
Geroy, I. J., Gribb, M. M., Marshall, H. P., Chandler, D. G., Benner, S. G., and McNamara, J. P.: Aspect influences on soil water retention and storage, Hydrol. Process., 25, 3836-3842, https://doi.org/10.1002/hyp.8281, 2011.

Harpold, A., Brooks, P., Rajagopal, S., Heidbuchel, I., Jardine, A., and Stielstra, C.: Changes in snowpack accumulation and ablation in the intermountain west, Water Resour. Res., 48, W11501, https://doi.org/10.1029/2012wr011949, 2012.

Harpold, A. A., Molotch, N. P., Musselman, K. N., Bales, R. C., Kirchner, P. B., Litvak, M., and Brooks, P. D.: Soil moisture response to snowmelt timing in mixed-conifer subalpine forests, Hydrol. Process., 29, 2782-2798, https://doi.org/10.1002/hyp.10400, 2015.

Harrington, R. and Bales, R. C.: Interannual, seasonal, and spatial patterns of meltwater and solute fluxes in a seasonal snowpack, Water Resour. Res., 34, 823-831, https://doi.org/10.1029/97wr03469, 1998.

Heilig, A., Mitterer, C., Schmid, L., Wever, N., Schweizer, J., Marshall, H. P., and Eisen, O.: Seasonal and diurnal cycles of liquid water in snow-Measurements and modeling, J. Geophys. Res.Earth, 120, 2139-2154, https://doi.org/10.1002/2015JF003593, 2015.

Hinckley, E.-L. S., Ebel, B. A., Barnes, R. T., Anderson, R. S., Williams, M. W., and Anderson, S. P.: Aspect control of water movement on hillslopes near the rain-snow transition of the Colorado Front Range, Hydrol. Process., 28, 74-85, https://doi.org/10.1002/hyp.9549, 2014.

Hunsaker, C. T., Whitaker, T. W., and Bales, R. C.: Snowmelt runoff and water yield along elevation and temperature gradients in California's Southern Sierra Nevada1, JAWRA J. Am. Water Resour. As., 48, 667-678, https://doi.org/10.1111/j.17521688.2012.00641.x, 2012.

Jencso, K., McGlynn, B., Gooseff, M., Wondzell, S., Bencala, K., and Marshall, L.: Hydrologic connectivity between landscapes and streams: transferring reach-and plot-scale understanding to the catchment scale, Water Resour. Res., 45, W04428, https://doi.org/10.1029/2008WR007225, 2009.

Jencso, K. G. and McGlynn, B. L.: Hierarchical controls on runoff generation: Topographically driven hydrologic connectivity, geology, and vegetation, Water Resour. Res., 47, W11527, https://doi.org/10.1029/2011wr010666, 2011.

Kampf, S., Markus, J., Heath, J., and Moore, C.: Snowmelt runoff and soil moisture dynamics on steep subalpine hillslopes, Hydrol. Process., 29, 712-723, https://doi.org/10.1002/hyp.10179, 2015.

Katsushima, T., Yamaguchi, S., Kumakura, T., and Sato, A.: Experimental analysis of preferential flow in dry snowpack, Cold Reg. Sci. Technol., 85, 206-216, https://doi.org/10.1016/j.coldregions.2012.09.012, 2013.

Kattelmann, R. and Dozier, J.: Observations of snowpack ripening in the Sierra Nevada, California, USA, J. Glaciol., 45, 409-416, 1999.

Koch, F., Prasch, M., Schmid, L., Schweizer, J., and Mauser, W.: Measuring snow liquid water content with low-cost GPS receivers, Sensors, 14, 20975-20999, https://doi.org/10.3390/s141120975, 2014.

Kormos, P., Marks, D., McNamara, J., Marshall, H., Winstral, A., and Flores, A.: Snow distribution, melt and surface water inputs to the soil in the mountain rain-snow transition zone, J. Hydrol.,
519, 190-204, https://doi.org/10.1016/j.jhydrol.2014.06.051, 2014.

Litaor, M. I., Williams, M., and Seastedt, T. R.: Topographic controls on snow distribution, soil moisture, and species diversity of herbaceous alpine vegetation, Niwot Ridge, Colorado, J. Geophys. Res., 113, G02008, https://doi.org/10.1029/2007jg000419, 2008.

Liu, F., Williams, M. W., and Caine, N.: Source waters and flow paths in an alpine catchment, Colorado Front Range, United States, Water Resour. Res., 40, W09401, https://doi.org/10.1029/2004wr003076, 2004.

López-Moreno, J. I., Revuelto, J., Gilaberte, M., Morán-Tejeda, E., Pons, M., Jover, E., Esteban, P., García, C., and Pomeroy, J. W.: The effect of slope aspect on the response of snowpack to climate warming in the Pyrenees, Theor. Appl. Climatol., 117, 207-219, https://doi.org/10.1007/s00704-013-0991-0, 2013.

Marsh, P.: Grain growth in a wet arctic snow cover, Cold Reg. Sci. Technol., 14, 23-31, 1987.

Marsh, P. and Woo, M.-K.: Meltwater movement in natural heterogeneous snow covers, Water Resour. Res., 21, 1710-1716, 1985.

McNamara, J. P., Chandler, D., Seyfried, M., and Achet, S.: Soil moisture states, lateral flow, and streamflow generation in a semiarid, snowmelt-driven catchment, Hydrol. Process., 19, 40234038, https://doi.org/10.1002/hyp.5869, 2005.

Mitterer, C., Heilig, A., Sweizer, J., and Eisen, O.: Upwardlooking ground-penetrating radar for measuring wetsnow properties, Cold Reg. Sci. Technol., 69, 129-138, https://doi.org/10.1016/j.coldregions.2011.06.003, 2011.

Molotch, N. P. and Meromy, L.: Physiographic and climatic controls on snow cover persistence in the Sierra Nevada Mountains, Hydrol. Process., 28, 4573-4586, https://doi.org/10.1002/hyp.10254, 2014.

Molotch, N. P., Colee, M. T., Bales, R. C., and Dozier, J.: Estimating the spatial distribution of snow water equivalent in an alpine basin using binary regression tree models: The impact of digital elevation data and independent variable selection, Hydrol. Process., 19, 1459-1479, 2005.

Molotch, N. P., Brooks, P. D., Burns, S. P., Litvak, M., Monson, R. K., McConnell, J. R., and Musselman, K.: Ecohydrological controls on snowmelt partitioning in mixedconifer sub-alpine forests, Ecohydrology, 2, 129-142, https://doi.org/10.1002/eco.48, 2009.

Musselman, K. N., Molotch, N. P., and Brooks, P. D.: Effects of vegetation on snow accumulation and ablation in a midlatitude sub-alpine forest, Hydrol. Process., 22, 2767-2776, https://doi.org/10.1002/hyp.7050, 2008.

Rasmussen, R., Ikeda, K., Liu, C., Gochis, D., Clark, M., Dai, A., Gutmann, E., Dudhia, J., Chen, F., Barlage, M., Yates, D., Zhang, G.: Climate Change Impacts on the Water Balance of the Colorado Headwaters: High-Resolution Regional Climate Model Simulations, J. Hydrometeorol., 15, 1091-1116, https://doi.org/10.1175/jhm-d-13-0118.1, 2014.

Richer, E. E., Kampf, S. K., Fassnacht, S. R., and Moore, C. C.: Spatiotemporal index for analyzing controls on snow climatology: application in the Colorado Front Range, Phys. Geogr., 34, 85-107, 2013.

Sexstone, G. A. and Fassnacht, S. R.: What drives basin scale spatial variability of snowpack properties in northern Colorado?, The 
Cryosphere, 8, 329-344, https://doi.org/10.5194/tc-8-329-2014, 2014.

Sommerfeld, R., Bales, R., and Mast, A.: Spatial statistics of snowmelt flow - data from lysimeters and aerial photos, Geophys. Res. Lett., 21, 2821-2824, https://doi.org/10.1029/94GL02493, 1994.

Storck, P., Lettenmaier, D. P., and Bolton, S. M.: Measurement of snow interception and canopy effects on snow accumulation and melt in a mountainous maritime climate, Oregon, United States, Water Resour. Res., 38, 5-1-5-16, https://doi.org/10.1029/2002wr001281, 2002.

Techel, F. and Pielmeier, C.: Point observations of liquid water content in wet snow - investigating methodical, spatial and temporal aspects, The Cryosphere, 5, 405-418, https://doi.org/10.5194/tc5-405-2011, 2011.

USGS: 3DEP products and services: The national Map, 3D Elevation Program Web page, edited, available at: http://nationalmap. gov/3dep_prodserv.html, last access: November 2015.

Webb, R. W.: Using ground penetrating radar to assess the variability of snow water equivalent and melt in a mixed canopy forest, Northern Colorado, Front. Earth Sci-PRC, 11, 482-495, https://doi.org/10.1007/s11707-017-0645-0, 2017.

Webb, R. W. and Fassnacht, S. R.: Snow Density, Snow Depth, and Soil Moisture at Dry Lake Study Site in Northern Colorado, 2013, Colorado State University, https://doi.org/10.1594/PANGAEA.864253, 2016a.

Webb, R. W. and Fassnacht, S. R.: Snow Density, Snow Depth, and Soil Moisture at Dry Lake Study Site in Northern Colorado, 2014, Colorado State University, https://doi.org/10.1594/PANGAEA.864254, 2016 b.

Webb, R. W. and Fassnacht, S. R.: Snow Density, Snow Depth, and Soil Moisture at Dry Lake Study Site in Northern Colorado, 2015, Colorado State University, https://doi.org/10.1594/PANGAEA.864255, 2016c.

Webb, R. W., Fassnacht, S. R., and Gooseff, M. N.: Wetting and drying variability of the shallow subsurface beneath a snowpack in California's Southern Sierra Nevada, Vadose Zone J., 14, 8, https://doi.org/10.2136/vzj2014.12.0182, 2015.
Webb, R. W., Fassnacht, S. R., Gooseff, M. N., and Webb, S. W.: The presence of hydraulic barriers in layered snowpacks: TOUGH2 simulations and diversion length estimates, Transport Porous Med., in review, 2018.

Webb, S. W.: Generalization of Ross' tilted capillary barrier diversion formula for different two-phase characteristic curves, Water Resour. Res., 33, 1855-1859, 1997.

Williams, C. J., McNamara, J. P., and Chandler, D. G.: Controls on the temporal and spatial variability of soil moisture in a mountainous landscape: the signature of snow and complex terrain, Hydrol. Earth Syst. Sci., 13, 1325-1336, https://doi.org/10.5194/hess-13-1325-2009, 2009.

Williams, M. W., Sommerfeld, R., Massman, S., and Rikkers, M.: Correlation lengths of meltwater flow through ripe snowpacks, Colorado Front Range, USA, Hydrol. Process., 13, 1807-1826, 1999.

Williams, M. W., Rikkers, M., and Pfeffer, W. T.: Ice columns and frozen rills in a warm snowpack, Green Lakes Valley, Colorado, USA, Nord. Hydrol., 31, 169-186, 2000.

Williams, M. W., Seibold, C., and Chowanski, K.: Storage and release of solutes from a subalpine seasonal snowpack: soil and stream water response, Niwot Ridge, Colorado, Biogeochemistry, 95, 77-94, https://doi.org/10.1007/s10533-009-9288$\mathrm{x}, 2009$.

Williams, M. W., Erickson, T. A., and Petrzelka, J. L.: Visualizing meltwater flow through snow at the centimetre-to-metre scale using a snow guillotine, Hydrol. Process., 24, 2098-2110, https://doi.org/10.1002/hyp.7630, 2010.

Williams, M. W., Hood, E., Molotch, N. P., Caine, N., Cowie, R., and Liu, F.: The "teflon basin" myth: hydrology and hydrochemistry of a seasonlly snow-covered catchment, Plant Ecol. Divers., 8, 639-661, https://doi.org/10.1080/17550874.2015.1123318, 2015.

Yamaguchi, S., Katsushima, T., Sato, A., and Kumakura, T.: Water retention curve of snow with different grain sizes, Cold Reg. Sci. Technol., 64, 87-93, https://doi.org/10.1016/j.coldregions.2010.05.008, 2010. 